\title{
El Teatro de virtudes de Sigüenza y Góngora: el desmantelamiento de la tradición y la innovación iconográfica
}

\section{The Teatro de virtudes by Sigüenza y Góngora: Dismantling of the Tradition and Iconographic Innovation}

\section{Citlalli Luna Quintana}

El Colegio de México

MÉXICO

citlali.luna@colmex.mx

[Hipogrifo, (issn: 2328-1308), 9.1, 2021, pp. 1141-1155]

Recibido: 09-12-2020 / Aceptado: 31-12-2020

DOI: http://dx.doi.org/10.13035/H.2021.09.01.64

Resumen. Mucho se ha estudiado el Teatro de virtudes... por ser uno de los hitos de la literatura novohispana del siglo XVII, sin embargo, se ha dejado de lado la innovación iconográfica que representaron los emblemas creados por Sigüenza y Góngora y lo que esto representó no nada más para la tradición emblemática, sino para la configuración de un ideal de gobernante. En este texto se hace un análisis de las fuentes iconográficas utilizadas por el novohispano, y un recorrido por el trastocado conjunto emblemático del Teatro de virtudes... para destacar las necesidades del reino que debe atender el nuevo virrey.

Palabras clave. Arco triunfal; emblemática; iconografía; literatura novohispana.

Abstract. The Theater of Political Virtues... has been studied extensively for being one of the landmarks of the literary movement in New Spain during the 17th century. However, the iconographic innovation of the emblems created by Sigüenza y Góngora, and their contribution to emblematic traditions and the portrayal of the ideal ruler, has not been analysed. This paper analyses the iconographic fonts used in 
New Spain and explores the emblems used in the Theater of Political Virtues... within the context of the needs of the realm that the New Spain viceroy must attend to.

Keywords. Triumphal arch; Emblematic; Iconography; New Spain literature.

Las «celebraciones triunfales» de los antiguos latinos llegaron al Renacimiento europeo y se extendieron por el mundo hispánico con toda la parafernalia que envolvía un doble objetivo: la fiesta de entretenimiento para el pueblo y una demostración ostentosa del poder político. Conforme transcurrieron los años de dominio español en América, las fiestas organizadas para las entradas de los virreyes y los arzobispos fueron aumentando su magnificencia y rebuscada pompa, a tal grado que se hizo necesario regularlas a través de las Leyes de Indias. En esta organización competían por el lucimiento los cabildos eclesiásticos con los cabildos de las ciudades, los gremios (algunos muy poderosos), las universidades e incluso los particulares -que los llegó a haber muy ricos e influyentes entre los mineros y los comerciantes-. Era de suponer que una figura como la del virrey cobrara tanta importancia dentro de la fiesta barroca novohispana, si los habitantes de la Nueva España sólo conocían a sus soberanos a través de las pinturas (los «reyes distantes», como los llamó tan acertadamente Víctor Mínguez¹): necesitaban partir de una figura concreta para colocar en su imaginario una representación efectiva de esa autoridad.

Como sabemos, estas prácticas festivas de los latinos llegaron a España du-

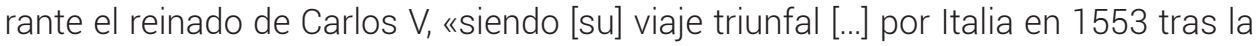
victoria de Túnez, el modelo que seguirá la mayoría de las entradas efectuadas en Europa y América» ${ }^{2}$ y, lo más importante, se mezclaron con una de las tradiciones literarias más enraizadas en el viejo mundo: los Speculum principium. Alfonso X fue el primer rey que consideró necesaria la creación de un manual que enseñara a su hijo -el futuro Sancho IV - cómo debía ser un príncipe. El espejo de príncipes, además de describir las virtudes que era necesario cultivar, las ejemplificaba con las grandes acciones de los reyes anteriores; así se creaba una genealogía de valores que conformaban la herencia moral innata del príncipe y justificaban su necesaria presencia en él. Pero no nada más era una lista de virtudes que debía poseer el futuro monarca, sino que el manual también era creado con la intención de educarlo para que siempre estuviera a la altura de las circunstancias que pedía su gobierno.

Como resultado de esta mezcla de tradiciones, encontramos en los arcos triunfales una exaltación de las virtudes del personaje a quien se dedicaba el arco, así como de las cualidades que poseían sus casas paterna y materna, además de las que ostentaba su familia; todo ello expresado por medio de alegorías que, al mismo tiempo, concebían un programa de las funciones a desempeñar como próximo gobernante, es decir, en los arcos triunfales se creaba la imagen de un virrey -o arzobispo - porque, junto al enaltecimiento y las muestras de lealtad, se orientaba al nuevo funcionario por el camino que debía transitar su gobierno y se le mostraban 
las necesidades más apremiantes del reino. De este modo, durante todo el dominio español, podemos encontrar

\begin{abstract}
unos virreinatos que mediante sus clases dirigentes rápidamente heredarán el ciclo festivo y ceremonial de la Europa del Renacimiento y Barroco van a necesitar una figura en que centrar el punto de vista en las fiestas, una cabeza visible que muestre el poder hispano en América: el todopoderoso virrey se va a convertir en el alter ego del monarca en tierras americanas, en el protagonista de las festividades y celebraciones, en el enviado y mano ejecutora del rey hispano, en definitiva, en el personaje de más alto rango que pisará la América hispana desde el siglo XVI al $\mathrm{XIX}$, entrando en sus ciudades con tanto boato y estruendo como si se tratase del monarca al que representa ${ }^{3}$.
\end{abstract}

Esta larga tradición, que duraría en España hasta bien entrado el siglo XIX, comenzó a decaer debido al auge del neoclasicismo y la ideología que propició las revoluciones burguesas. En la Nueva España se cultivó este género festivo con singular ahínco; muy pronto se erigieron arcos para celebrar la entrada de aquellos que serían representantes del rey en este orbe. El primer antecedente directo de esta fiesta se encuentra en el viaje que hizo Hernán Cortés para llegar a lo que sería más tarde la Ciudad de México. Seguirían este mismo itinerario todos los virreyes a su llegada. Si bien es cierto que el primer arco triunfal a un virrey o un arzobispo documentado en la Nueva España fue el que se erigió en honor de fray García Guerra en 1608, Bernal Díaz del Castillo da la noticia de algunos arcos que fueron hechos setenta años antes como parte de las celebraciones de la paz consolidada entre Carlos V y Francisco I en 1538:

Y acordaron [Hernán Cortés y Antonio de Mendoza] de hacer grandes fiestas y regocijos; y fueron tales, que otras como ellas, a lo que a mí me parece, no las he visto en Castilla, así de justas y juegos de cañas, y correr toros, y encontrarse unos caballeros con otros, y otros grandes disfraces que había en todo. Esto que he dicho no es nada para las muchas invenciones de otros juegos, como solían hacer en Roma cuando entraban triunfantes los cónsules y capitanes que habían vencido batallas, y los petafios y carteles que sobre cada cosa había. Y el inventor de hacer aquellas cosas fue un caballero romano que se decía Luis de León, persona que decían era de linaje de los patricios, natural de Roma4.

José Morales Folguera considera que fueron dos los arcos triunfales que marcaron el modelo de todos los que se erigirían durante el dominio peninsular en la Nueva España: el ya mencionado, que se construyó para fray García Guerra, el cual «marcó pautas en el señalamiento de comportamientos y en la apropiación de los lugares claves del espacio urbano en México» ${ }^{5}$ y el que se erigió para la llegada del marqués de Villena en 1640 que «destacó por el lujo y el derroche económico gastado por las autoridades locales en agasajarle con unos festejos, que duraron 
más de dos meses, desde que llegó a Veracruz» 6 . Así, las celebraciones siguientes se harían con el espacio e itinerario definidos por el primero y con la liberalidad y los lujos del segundo.

Pero no todos los arcos triunfales se erigieron siguiendo estos modelos: Carlos de Sigüenza y Góngora ideó uno que soslayaría toda la tradición clásica de la emblemática y propondría una revolución en las concepciones estéticas de la llamada «fiesta barroca» en la Nueva España. Me refiero al Teatro de virtudes políticas que constituyen a un príncipe; advertidas en los monarcas antiguos del mexicano imperio... ${ }^{7}$ un arco triunfal creado para festejar la llegada de Tomás Antonio de la Cerda y Aragón, conde de Paredes y marqués de la Laguna, quien sería el vigésimo octavo virrey de la Nueva España.

La gran innovación de Sigüenza en este arco consistió en el reemplazo de las alegorías de los dioses grecolatinos por las de los antiguos dioses y emperadores aztecas; este hecho, además de representar una especie de rechazo a la tradición grecolatina, constituye una creación de alegorías, es decir, antes del Teatro de virtudes políticas... no se consideraba que Huitzilopochtli pudiera representar la imagen del conductor y caudillo o que Itzcohuat ${ }^{8}$ fuera el ícono de la Prudencia. Debido a la novedad del tema, no es muy común la idea de que este arco llevara la intención de restituir o incluir el pasado indígena en la tradición, es decir, que también se convirtiera en un lugar común hablar de emperadores o dioses prehispánicos, así como lo venía siendo acudir al panteón grecolatino.

Además de esta inclusión iconográfica, muchos estudiosos sugieren que en el Teatro de virtudes políticas... hay un germen ideológico que años más tarde se convertiría en uno de los pilares del movimiento independentista. Un ejemplo de este tipo de interpretaciones se encuentra en José Rojas Garcidueñas:

La manera como trata las cosas de México revela un sentimiento más hondo y más grande. Como símbolos de las virtudes que debe tener el estadista, y que por adulación suponían adornaban al entrante conde de Paredes, a Sigüenza se le ocurrió poner nada menos que a los antiguos Reyes o Señores de México precortesiano, lo cual no solamente resultaba de gran originalidad en esa época, en que siempre buscábanse los trillados símbolos y alegorías de la mitología clásica sino que, cosa mucho más importante, significaba una verdadera reivindicación de un pueblo que siglo y medio antes había sido vencido y dominado por el régimen que el festejado virrey directamente representaba ${ }^{9}$.

Otra vertiente de estas lecturas del Teatro de virtudes políticas... es la de Antonio Lorente quien dice que «la identificación del México criollo -el aquí y ahora de Sigüenza- con el pasado precortesiano - no español- se combina con el elogio a la

6. Morales Folguera, 1991, p. 102.

7. Sigüenza y Góngora, Teatro de virtudes políticas que constituyen a un príncipe..., 1680. En adelante sólo pondré el número de página en el cuerpo del texto.

8. Todos los nombres de los emperadores prehispánicos serán escritos con la forma y la ortografía que utiliza Sigüenza y Góngora.

9. Rojas Garcidueñas, 1945, pp. 122-123. 
alta genealogía del virrey, conde de Paredes y anticipa con claridad su sentimiento indigenista» ${ }^{10}$. Es cierto que en Carlos de Sigüenza y Góngora hay una preocupación por la identidad criolla, pero de ninguna manera responde a un atisbo de la ideología independentista y, mucho menos, a un sentimiento indigenista. Desde las primeras décadas de la Conquista, hubo una clara distinción entre los españoles que llegaban a la Nueva España y los que habían nacido en esta tierra; el médico sevillano Juan de Cárdenas fue uno de los primeros en escribir al respecto en 1591:

\begin{abstract}
Para dar muestra, y testimonio cierto, de que todos los nacidos en Indias sean a una mano de agudo tracendido y delicado ingenio, quiero que comparemos a uno de los de acá con otro recien venido de España, y sea esta la manera, que el nacido en las Indias no sea criado en alguna de estas grandes y famosas ciudades de las Indias, sino en una pobre y bárbara aldea de indios, solo en compañía de cuatro labradores, y sea asimismo el gachupín o recien venido de España criado en aldea, y júntense estos que tengan plática, y conversación el uno con el otro, oiremos al español nacido en las Indias, hablar tan pulido cortesano y curioso, y con tantos preámbulos de delicadeza y estilo retorico, no enseñado ni artificial, sino natural que parece ha sido criado toda su vida en corte, y en compañía de gente muy hablada y discreta, al contrario verán al chapetón, como no se haya criado entre gente ciudadana, que no hay palo con corteza que más bronco y torpe sea, pues ver el modo de proceder en todo del uno tan diferente del otro, uno tan torpe, y otro tan vivo, que no hay hombre por ignorante que sea, que luego no eche de ver, qual sea gachupín, y cual nacido en Indias: pues venga ahora una mujer de España, y entre en conversación de muchas damas de las Indias, al momento se diferencia y conoce ser de España, sólo por la ventaja que en cuanto al trascender, y hablar nos hace la española gente nacida en Indias, a los que de España venimos... ${ }^{11}$
\end{abstract}

Este tipo de argumentos responden al sentimiento que, durante años, fue cultivándose en la mentalidad criolla; muchos americanos consideraban injusto que los puestos importantes de las administraciones civil y eclesiástica fueran otorgados a los peninsulares recién llegados y ellos, españoles también, no pudieran acceder a esos empleos a pesar de que, como era obvio, conocían mejor los problemas económicos, políticos y administrativos del virreinato. Este sentimiento de marginación se exacerbó muy tempranamente, desde mediados del siglo XVI, cuando fueron suspendidas las encomiendas y muchos criollos se quedaron sin heredad y sin los privilegios que, como descendientes directos de los conquistadores, venían usufructuando y, en estricto derecho, les correspondían.

Así pues, Sigüenza está haciendo eco de estas inconformidades que flotaban día a día en el ambiente intelectual de los criollos novohispanos y no a un sentimiento de identidad nacional e independencia en el sentido que se ha querido creer durante muchos años; ellos, los criollos, sólo querían obtener los puestos que creían merecer y no sentirse relegados por la Corona ni desplazados por los españoles peninsulares - casi siempre menos capacitados- que obtenían las prebendas con sus medros en la Corte y llegaban a la Nueva España con los nombramien-

10. Lorente, 1996, p. 21.

11. Cárdenas, Primera Parte de los Problemas y secretos maravillosos de las Indias, p. 159. 
tos en las manos. Justo es por esa razón que entre los intelectuales de la época se estaba creando un sentimiento de identidad, pero no patriótica ni libertaria, sino una que configuraba la identidad de un grupo que se había propuesto reafirmar sus capacidades y sus derechos frente a los privilegios de los peninsulares recién llegados; buscaban que no se les tratara con menosprecio porque, como ya dije, apenas transcurridos unos treinta años de la Conquista, comenzó a notarse un desdén hacia ellos que venía desde las altas esferas de la Corona.

De cualquier modo, no se debe olvidar que este supuesto sentimiento de identidad e independencia no podía surgir en pleno siglo XVII en el pensamiento de los españoles americanos, ni siquiera en el de los europeos. Sería hasta los años previos a la Revolución Francesa, con el surgimiento de las ideas burguesas de nación, la postulación de los derechos del hombre, las teorías del estado, los ideales de «Libertad, Igualdad y Fraternidad» entre los hombres, cuando toda esta ideología inundaría las mentes de aquellos que promovieron el pensamiento revolucionario, con el cual se inspiraría la independencia de las trece colonias inglesas y, transcurrido todo ese vuelco del pensamiento, se iluminaría la posibilidad para los novohispanos de desligarse de la tutela de la corona española.

Pero eso ocurriría muchos años después de la época que nos ocupa, volvamos a 1680. La entrada de un virrey era todo un acontecimiento: se levantaban arcos, se hacían fiestas con grandes comilonas, mascaradas, paseos matutinos, se organizaban corridas de toros, misas, novenarios, etc.; todo estaba cifrado para recordar el primer viaje que hizo Hernán Cortés a la Ciudad de México:

Tlaxcala, aliada de los conquistadores, era la capital de la "república de los indios"; Puebla, ciudad construida por y para españoles, según los designios milenaristas de los primeros franciscanos, simbolizaba social y espiritualmente el polo criollo. Otumba, recordatorio de la resonante victoria de Cortés, era el lugar elegido para el encuentro y la transmisión del mando entre el virrey entrante y el saliente. La visita del nuevo virrey a Guadalupe revestía especial significación: comenzar su gobierno bajo la advocación de la Virgen de Guadalupe era un gesto de religiosidad y tacto político que satisfacía a la poderosa facción criolla, que concretaba sus ideales patrióticos en su ferviente guadalupanismo. Chapultepec era el palacio de retiro de los virreyes, a pocos kilómetros de México, donde recibía a las autoridades locales mexicanas antes de la toma de posesión solemne, y desde donde estaba al corriente de los preparativos de la fiesta con que concluía su entrada triunfal a México ${ }^{12}$.

Así, todo este recorrido constituye la creación de un entramado simbólico entre la llegada de Cortés y su camino hacia la conquista del territorio y la consolidación de la religión católica como única y verdadera; entonces, la entrada de un virrey también significa la conjunción de una conquista militar y una espiritual en el Nuevo Mundo. La cúspide de este gran evento era la entrada a la Ciudad de México. Y con la llegada del virrey Marqués de la Laguna en 1680, se habían de erigir dos arcos que coincidieran con el recorrido procesional que hacía el gobernante para 
confirmar el ritual cortesiano: uno de los arcos se levantaría al final de la calle de Santo Domingo, y sería costeado por el Cabildo de la Ciudad de México y, el otro, se erigiría en la Catedral Metropolitana y sería patrocinado por el Cabildo Eclesiástico.

Ya para 1680 sor Juana Inés de la Cruz gozaba de gran fama entre los intelectuales y religiosos novohispanos y Carlos de Sigüenza y Góngora era un reconocido erudito, astrólogo del rey, catedrático de la Universidad, etcétera; ambos se encontraban entre las mentes más brillantes de todo el virreinato y fueron destinados para el mismo fin: confeccionar una muestra de lealtad para el virrey conde de Paredes, así como su apología, en sendos arcos triunfales. Esto, necesariamente, implicaba un gran esfuerzo intelectual y de ingenio.

No debemos considerar verdadera aquella supuesta rivalidad entre ambos pensadores y a la que Francisco de la Maza dedica su «Sor Juana y Don Carlos. Explicación de dos Sonetos hasta ahora confusos» ${ }^{13}$. Es innegable pensar que había una competencia - pero no una enemistad- por fraguar el programa iconográfico más novedoso y, sobre todo, más erudito. Es ahí precisamente donde el gran ingenio de Sigüenza supera al de sor Juana; esto no demerita, por supuesto, la ingente sabiduría que permea el Neptuno alegórico, sin embargo, el programa del catedrático implica una ruptura con la tradición emblemática y una propuesta de renovación estética y eso, pese a todo lo que el arco de la monja aporta, no tiene parangón en los trescientos años que vivió la Nueva España.

Veamos cómo es esta ruptura y en qué consisten las innovaciones de esta propuesta estética formulada por Sigüenza ${ }^{14}$. Empecemos por la elección de las alegorías: sor Juana eligió seguir la tradición clásica y utilizar a un dios grecolatino que representara al conde de Paredes - desde luego que no sería Júpiter, reservado para la figura de los reyes, quien además no tenía ningún nexo con el virrey- y nadie resultó mejor que Neptuno, la mayor deidad de las aguas y hermano del soberano de los dioses y de los hombres, como diría el otro Góngora, don Luis, en la estrofa 51 del Polifemo...: «Del Júpiter... de las ondas». Uno de sus títulos, «Marqués de la Laguna», empata perfectamente con la naturaleza hidráulica de la Ciudad de México y con los atributos del dios del tridente, resulta, por tanto, de enorme pertinencia su nombramiento como representante del rey en la más importante de las colonias americanas que sufría por las frecuentes inundaciones y, paradójicamente, por prolongadas sequías.

Sigüenza y Góngora estaba consciente de que no podía competir en el mismo terreno poético donde se desempeñaba sor Juana; su manejo más ágil de los versos y la ingeniosa ocurrencia de las fábulas, componían un ámbito donde la monja

13. Maza, 1966, pp. 190-204.

14. Las declaraciones de Sigüenza en el segundo de los «preludios» del Teatro de virtudes políticas.. han hecho que los historiadores y los críticos quisquillosos postulen una fuerte rivalidad entre Sigüenza y sor Juana. Dos veces repite Sigüenza la idea de que «mendigar extranjeros héroes» «era agraviar a su patria» (se refería a los romanos) y en la segunda alusión se refiere explícitamente a la Nueva España: «en los mexicanos emperadores, que en realidad subsistieron en este emporio celebérrimo de la América, hallé sin violencia lo que otros tuvieron necesidad de mendigar en las fábulas». Las «fábulas» son las historias de la mitología grecolatina. 
estaba más avezada. Ambos conocían bien la tradición, pero - hay que decirlo- el talento de sor Juana para escribir poesía era muy superior al del catedrático; por eso mismo, don Carlos eligió desempeñarse en otro terreno: tuvo que ser más osado y por eso prefirió romper completamente el molde donde se venían haciendo las alegorías de los arcos triunfales y, por tanto, de la fiesta barroca novohispana.

Fue un vuelco inesperado. La cultura simbólica se conformaba desde la primera edición del Emblematum liber (1531) de Alciato, pasando por emblematistas como Sebastián y Juan de Horozco y Covarrubias, Aquiles Bocci, Juan de Borja, Saavedra Fajardo; los mitógrafos como Ovidio, Bocaccio o Pérez de Moya; los iconógrafos como Piero Valeriano o Cesare Ripa y los filósofos como León Hebreo o Atanasius Kircher, todos ellos fueron los que forjaron las concepciones artísticas y los modos de representación en boga. Con la propuesta de Sigüenza cambiaron completamente los paradigmas. Durante cerca de doscientos años, cada programa iconográfico venía mezclando imágenes, tradiciones y maneras de plasmar las diferentes alegorías de las que se servía el discurso. Como resume Mínguez:

Tres son, así, los ámbitos iconográficos más relevantes en los arcos triunfales barrocos americanos, tanto en Puebla como en México, Lima o Potosí: la utilización de la mitología clásica como reflejo de virtudes, de la historia romana y principalmente sus emperadores como espejo de príncipes, o el uso de las emblematas europeas para encontrar motivos con los que decorar esas fachadas efímeras, en el caso enunciado dos emblemas que son propios de la Monarquía hispánica, y normalmente se utilizan para el rey, como el sol y el león ${ }^{15}$.

Sigüenza dejó a un lado esta tradición - sólo conservó a Alciato- con más de siglo y medio de popularidad y decidió crear su propia iconografía y, por tanto, también hizo la equivalencia entre los diferentes emperadores prehispánicos y la alegoría que cada uno había de «encarnar». Por más innovador que parezca, en el fondo lo único con lo que rompió su aparente revolución fue con el contenido de la iconografía, porque siguió utilizando la misma estructura triplex del emblema (mote, imago o res picta y epigrama) y mantuvo el objetivo último de formular, por un lado, un espejo de príncipes y, por el otro, componer la imagen ideal del virrey, es decir, las mismas metas que había tenido la erección de arcos triunfales con la iconografía tradicional desde sus inicios. Su programa seguía respondiendo a los dos valores que se buscaba exaltar: virtud y lealtad. Esta es la imagen que, según don Carlos, debía tener el virrey de la Nueva España, proyectada a través de su «aindiado» -como lo llama Lorente- espejo de príncipes.

Debía ser, como aparece Huitzilopochtli en el emblema que abre el arco, conductor y caudillo de su pueblo. La inclusión de este personaje es muy simbólica puesto que, como sabemos, no es propiamente uno de los emperadores prehispánicos, sino un dios, aquel que guió al mítico pueblo nahua para encontrar la laguna y fundar un imperio sobre ella. Llama la atención que el elemento iconográfico más sobresaliente de la imago sea el del brazo empuñando una antorcha, símbolo que enfatiza el carácter de «guía» del pueblo adjudicado a Huitzilopochtli. Es evidente

15. Mínguez, 2012, pp. 91-92.

HIPOGRIFO, 9.1, 2021 (pp. 1141-1155) 
que Sigüenza no podía manejar a la ligera estos simbolismos, por esa razón, en los doce emblemas del arco siempre incluye una justificación religiosa (cristiana) de la alegoría que propone; en este caso, el emblema en su totalidad representa la importancia que debe dar el virrey a los actos conducidos por Dios, es decir, todas las acciones de gobierno deben de tener su origen en Dios o, de otro modo: «no hay imperio que no proceda de Dios» (p. 289). No podemos dejar de mencionar que el ex jesuita, después de la écfrasis que acompaña al epigrama, se da el lujo de seguir comentado la idea principal del emblema, lo cual representa también otra innovación en la estructura de los relatos de este tipo de fiestas barrocas, lo usual hubiera sido, después del epigrama, continuar con la écfrasis del siguiente emblema.

La siguiente alegoría es la de Acamapich, quien representa la Esperanza. Este personaje sí es un emperador prehispánico y Sigüenza le adjudica este valor debido a que aceptó gobernar el imperio en tiempos aciagos, con la esperanza de hacer prosperar a su pueblo. Así, el nuevo virrey debe ser como Acamapich y, pese a las dificultades, debe comprometerse a trabajar para que las condiciones del virreinato mejoren. La écfrasis de este emblema es sumamente interesante ya que identifica el nombre del emperador con el de la caña, dice que en la pintura se encuentran la Esperanza y la Fama, pero no las describe. No sabemos si estas alegorías fueron hechas siguiendo los modelos de Ripa o de Alciato, algo similar podría ocurrir con las figuras del laurel y la palma, pertenecientes a Alciato.

De igual manera, más adelante hace una disertación sobre las cañas que fueron símbolo del reinado de Acamapich y aquella que le impusieron a Cristo como cetro cuando Pilatos lo presentó ante el pueblo: «llevaba la caña que le habían dado, muy semejante a cetro de reino mundano, que por ser mudable muy frecuentemente se le considera frágil, vacío, leve» (p. 296). Sigüenza aprovecha para hacer una fuerte crítica sobre lo frágil que puede llegar a ser el cetro de un rey - símbolo de mando-, muchas veces hueco por dentro y fácil de romper, por eso termina con una sugerencia: «Sería próvido presagio de nuestra dicha el que el mexicano gobierno se principiase entre las cañas de una laguna, porque así como de ellas se originó la música [...], de la misma manera se continúa su economía con la armonía y ajustado compás» (pp. 296-297). En este pasaje es posible ver el sentimiento criollo que he venido comentando: sería propicio que alguien que se originó entre las cañas de la laguna -alguien que nació en Nueva España- ayudara en el gobierno, puesto que, como conoce la música -la economía, administración, política, etc.- sabe cómo mantener el compás, es decir, el buen gobierno.

El siguiente emblema está protagonizado por Huitzilihuitl, quien sugiere la afabilidad y clemencia que debe poseer un príncipe: «formar leyes para la dirección de los súbditos es obligación de los príncipes, pero el que las observen aquellos más que disposición de su arbitrio es consecuencia de la afabilidad de su trato. No hay armas más poderosas para develar la protervia humana que la clemencia» (p. 301). Lo que más pondera Sigüenza y Góngora del reinado de este emperador azteca es haber conseguido y mantenido la paz y quietud para su pueblo y el hecho de haber dejado el gobierno ordenado gracias a la promulgación de varias leyes. También se le da mucho peso a la clemencia del gobernante, sin embargo, hacia el final de la 
reflexión, Sigüenza sugiere que no por ser clemente significa que el príncipe debe parecer débil y temer usar las armas. El catedrático plantea una imagen del virrey bastante clara en este emblema: debe ser afable, clemente y, cuando sea necesario, valeroso en las contiendas.

En el cuarto emblema encontramos a Chimalpopocatzin, en él se hace una disertación sobre la autoridad que deben tener los príncipes, para eso, cita a Jo. Altus: «Ni la república ni el rey son para el rey, sino que el rey o cualquier otro magistrado son para el reino y la ciudad. Pues el pueblo es por naturaleza y por tiempo anterior, mejor y superior que sus gobernantes, así como los componentes son anteriores y superiores al compuesto» (p. 308). Es sugerente el interés que tiene Sigüenza y Góngora por recalcar la calidad de «servidores del pueblo» que tienen los gobernantes, de ahí que más adelante pondere la lucha contra la tiranía y la valentía que se necesita para poder, si es necesario, dar la vida por la patria, como lo hizo Chimalpopocatzin: «haber sido él el que con su vida libertó a su república y patria de la opresión del tirano. Eso fue saber desempeñarse de las obligaciones que le puso la corona, transformándose en escudo para defender a los suyos» (pp. 312-313). Culmina de manera magistral esta idea con una creencia común que aparece en los bestiarios, donde el Pelícano, al abrirse el pecho para resucitar o alimentar a sus polluelos, se convierte en una alegoría de Cristo y del sacrificio que hace para resucitar a sus hijos ${ }^{16}$; así, el gobernante debe sacrificar su vida para salvar a su pueblo.

La alegoría del emblema quinto está encarnada por Itzcohuatl quien, como ya mencioné, representa la Prudencia. La idea queda perfectamente expresada en la décima espinela que acompaña al emblema:

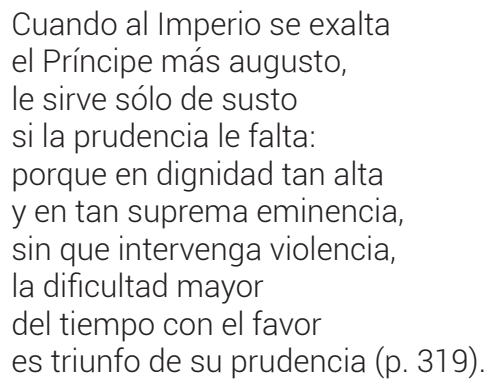

En estos versos se manifiesta la idea de que una virtud como la Prudencia es afín a la alta dignidad que su rango conlleva puesto que, al gobernar, son muchas las dificultades que necesitará sortear y es sólo gracias a la prudencia del príncipe que estos problemas serán resueltos; así también debe ser un virrey.

El emblema seis, donde encontramos a Motecohzuma Ilhuicaminan representando la Piedad que debe tener un príncipe, sobre todo la que es necesaria mos-

16. La idea también se encuentra en la emblemática, pero proviene de los bestiarios medievales. En su tratado, Juan de Aranda dice: «El Pelicano saca sus hijos muertos de los huevos, y se hiere el pecho con su pico, y se saca sangre con la cual los rocía y así los resucita» (Lugares comunes de conceptos, dichos y sentencias, en diversas materias, p. 204). 
trar al respetar la religión. La écfrasis refuerza esta idea al representar una saeta arrojada por el emperador hacia el cielo; la flecha simboliza la oración que debe ser esparcida en todo el pueblo y que debe llegar a los lugares más remotos. Sigüenza fortalece esta idea con un fragmento de san Ambrosio: «la oración, aunque más lejos, como la flecha, hiere; la flecha no sólo llega al adversario que está cerca, la oración también vulnera al enemigo que se encuentra lejos» (p. 324) y condensa todo en el epigrama del emblema que está conformado por dos redondillas:

\author{
Sagradas ardientes flechas \\ con piadosas intenciones \\ son armas las oraciones \\ que al cielo suben derechas. \\ Con estas armas no dudo \\ que quien las previene fiel \\ tiene con Dios buen cuartel, \\ y en ellas tiene su escudo (p. 325).
}

La alegoría del emblema siete es de la Fortaleza, representada en el emperador Axayacatzin. La historia de este emperador cuenta que luchó contra todas las calamidades de su pueblo, fue siempre el primero en salir a la batalla; se pondera su gran valentía en la décima espinela que acompaña al emblema:
De contrarios combatido, al pecho más esforzado que siendo siempre asaltado jamás se advirtió vencido: si en los hombros substenido tuvo un mundo, y su grandeza manteniendo con firmeza todo el Orbe Mexicano, es justo que de su mano lo premie la Fortaleza (p. 331).

Aquí, Sigüenza y Góngora sugiere que el virrey tiene que estar consciente de que lleva sobre los hombros todo el Orbe y, lo más importante, debe tener la fortaleza que se necesita para mantener la gloria que tiene, puesto que será «de todos combatido». Esta idea de la responsabilidad que tendrá el nuevo gobernante ante la grandeza del orbe se expresa con más solemnidad en la écfrasis: «se pintó inclinado [el rey azteca], sino para indicar cuánta es la gravedad del imperio, que no sólo a él, sino a todos los superiores oprime» (p. 332), es decir, el imperio es más grande que un virrey o un rey, y es necesario poseer conciencia de esa grandeza y, por tanto, también se necesita tener presente que los gobernantes cambian, pero la grandeza del imperio prevalece.

El emblema ocho, representado por Tizoctzin, es una alegoría de la Paz y el Orden como virtudes que debe cultivar el virrey. Una de las cosas más relevantes de este tablero es la imago: está llena de movimiento, recuerda incluso la enorme vita- 
lidad que despliega la écfrasis de Homero en la descripción del escudo de Aquiles ${ }^{17}$, imágenes que Sigüenza seguramente tenía en mente a la hora de describir la res picta de este emblema: «Se pintó la paz y la guerra, [...] apartábase Tizoc de aquélla [la Guerra] con ligerísimos pasos, acercándose a ésta [la Paz] por entre un zarzal, cuyas espinas le taladraban los pies y piernas, que se veían llenas de heridas» (pp. 334-335), la escena es extraordinaria: está cargada de movilidad, incluso señala los pasos ligeros con los que el emperador camina y, a manera de panning, Sigüenza guía la mirada del lector para que observe la forma en que las espinas hieren los pies y las piernas del personaje, tiñendo sus miembros de pequeñas heridas.

En este emblema tenemos una petición directa al conde de Paredes:

La paz que para los suyos solicita México en esta empresa, por medio del excelentísimo señor marqués de la Laguna, es la que Beyerlinck [...] define así: «La mejor y plena definición de la paz, cuando hablamos de ella, consiste en que haya cierta concordia del alma con Dios, consigo misma y con el prójimo» (pp. 335-336).

Es la primera vez en todo el arco que Sigüenza interpela directamente al virrey con una demanda; además, reafirma la idea esbozada más arriba sobre la llegada de un virrey, sólo que en esta ocasión habla no nada más es sobre la llegada, sino también sobre el gobierno: debe ser pacífico, esto quiere decir que haya en él la conjunción de valores religiosos, políticos y, sobre todo, respeto al prójimo; aquí, nuevamente Sigüenza deja ver la necesidad de esta justicia para los criollos que tanto le preocupa.

En el emblema nueve está representado Ahuitzotl y alude a la importancia de escuchar los consejos. Es la primera vez que Sigüenza utiliza un contra-ejemplo: los gobernantes prehispánicos anteriores poseyeron las virtudes que pondera y es por estas mismas que los alaba; en el caso de Ahitzotl, él no escuchó los consejos que le dieron y se precipitó para llevar a la ciudad agua desde Coyoacán, lo que provocó la inundación de la misma y la muerte de este emperador. Aquí encontramos otra de las innovaciones estéticas del astrólogo: en la literatura emblemática no es común dar contra-ejemplos, puesto que el carácter didáctico del emblema permite establecer un juego entre palabra e imagen y, por tanto, los contra-ejemplos romperían o complicarían demasiado esta dinámica. Además, el autor también alude a la humildad que el gobernante debe tener para escuchar el consejo de los ancianos.

La imago del emblema diez está representada por Motecohzuma Xocoyotzin. Aquí se ponderan, sobre todo, la Humildad, el Amor y la Liberalidad con que el emperador trataba a su pueblo, incluso a los españoles, quienes lo tenían preso en su propio palacio. Dice Sigüenza que «los príncipes no tienen otra cosa más que los inmortalice que la liberalidad y magnificencia» (p. 343), estos valores se suman a la imagen que el autor está creando del nuevo virrey. Pide que trate a su pueblo con amor, humildad y liberalidad para de este modo ganar la lealtad y amor de los súbditos. Esta idea se reafirma en la décima, también espinela, que acompaña al emblema: 


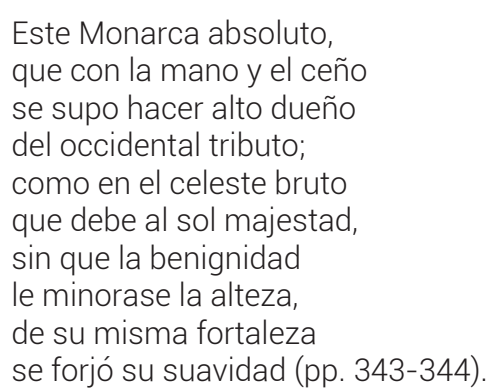

Con estos maravillosos versos, Sigüenza, aunque usando la imagen del monarca y no la del virrey, dice que, pese al gran poder que se tiene al gobernar, estos valores no son una debilidad, sino que un gobernante también es fuerte al profesar amor, humildad y liberalidad hacia su pueblo y, por tanto, como no lo debilitan, aumentan su magnificencia.

En el emblema once se pondera la audacia de Cuitlahuatzin y, por tanto, la que debe tener el nuevo virrey. Al emperador azteca se le reconoce el haber aceptado el gobierno en condiciones adversas, cuando era necesario seguir luchando contra Hernán Cortés; él estaba al frente cuando pasó la «Noche triste». Llama la atención que, en varios emblemas, Sigüenza recalque los valores que debe tener un gobernante cuando su pueblo está en desgracia, podría ser que, efectivamente, sea un homenaje a estos emperadores, o que esté exagerando la situación en la que se encontraba el virreinato en ese momento, puesto que si bien es cierto que en un gobierno siempre hay crisis y que en los pueblos constantemente hay carencias y problemas, el estado de la Nueva España en esa época no era tan precario como para hacer ese tipo de comparaciones.

El emblema doce culmina esta serie de imágenes de emperadores, Cuauhtémoc es quien la cierra con la idea de que un gobernante tiene que tener constancia en la lucha contra las adversidades y honor en la derrota. Si seguimos la historia de estos emperadores, sabemos que no había opción para otro final, sin embargo, es un cierre complicado para una relación que, por un lado, está festejando la llegada de un virrey y, por otro, tiene la intención de ser una muestra de lealtad.

Este arco triunfal es, sin duda, uno de los más osados que se erigieron en la Nueva España. Como se ha visto, desmantela una tradición emblemática para crear, en palabras de Mínguez, una «identidad iconográfica». Llama la atención que, además de este vuelco en las imágenes, también olvide casi por completo el ensalzamiento del personaje al que se erige el auto. Sólo al principio del relato hay una exaltación al conde de Paredes y, fuera de la «sugerencia» directa que ya comenté, no se ocupa del personaje al que tiene que alabar.

Una de las construcciones simbólicas que el arte de los conquistadores proyecta propagandísticamente sobre la sociedad virreinal desarrolla el tema iconográfico del espejo de los antepasados, o lo que nosotros hemos llamado «la imagen dinástica»: muchos catafalcos y arcos de triunfo exhiben retratos pintados, o más habitualmente, esculpidos, de los reyes que han precedido al monarca 
reinante en el trono, dando lugar a verdaderas apoteosis familiares que, evidentemente, además de recordar a los súbditos ultramarinos las glorias habsbúrgicas, borbónicas o, sencillamente hispanas [...] evidencian que la continuidad dinástica está garantizada, con todo lo que implica de lealtad al orden establecido. En este contexto los reyes aztecas recuperados por Sigüenza constituyen toda una osadía política, y explicitan otra mirada criolla al pasado prehispánico ${ }^{18}$.

Por un lado, no nada más constituye una mirada hacia el pasado prehispánico, sino que Sigüenza hace precisamente del tema un pretexto para denunciar el olvido que ha tenido la Corona hacia los criollos; ellos también son españoles y los peninsulares no los consideran como tales. Hacer una muestra de lealtad hacia el virrey -más específicamente, a la Corona-, resulta demasiado complicado puesto que se trata de mostrar lealtad a quien sólo ha demostrado olvido y desdén. En eso parece consistir el tema principal de este arco triunfal: en la imposibilidad de mostrar lealtad a quien no los considera como parte de un sistema político, a quien no los incluye, a quien les quita privilegios y merecimientos que les son propios por naturaleza, etc. Pero este mensaje no es, de ninguna manera, tan evidente y el recuento de este pasado indígena va encaminado a incorporar una tradición que no se había tomado en cuenta, pero que también es parte de los elementos que conforman el reino de la Nueva España.

Por otro lado, queda muy clara la intención de crear un espejo de príncipes, pero la ruptura y audacia del autor radica en la elección de los reyes en los que sustenta su propuesta genealógica; siguiendo la tradición, el virrey debería de poseer - o cultivar - las cualidades que sus antecesores poseyeron, ahí precisamente es donde radica la osadía de Sigüenza: en su propuesta por cimentar las bases de un gobernante virreinal no en las antiquísimas casas dinásticas españolas, sino en las prehispánicas, ahí también está desmantelando la tradición de los Speculum Principium que se atienen sólo a los valores europeos.

En suma, podemos decir que el Teatro de virtudes políticas... es una gran propuesta ética y a la vez estética, cuyo autor tiene la audacia de tomar la tradición en sus manos y desmantelarla: usar el molde, modificarlo, incluir el pasado prehispánico, dejar de lado a los grandes emblematistas, crear alegorías diferentes, nuevas imágenes, etc.; pero no nada más es eso, también se trata de una denuncia (comedida y velada) que debe escuchar la Corona, es un recordatorio de que acá, en el otro Orbe, los criollos también son españoles.

\section{BibliografíA}

Alciato, Andrea, Emblemas, ed. Santiago Sebastián, Madrid, Akal, 1985.

Aranda, Juan de, Lugares comunes de conceptos, dichos y sentencias, en diversas materias, Sevilla, Juan de León, 1595. 
Cárdenas, Juan de, Primera Parte de los Problemas y secretos maravillosos de las Indias, México, Museo Nacional de Arqueología, Historia y Etnología, 1913.

Díaz del Castillo, Bernal, Historia verdadera de la Conquista de la Nueva España, Madrid, Espasa-Calpe, 1968.

Lorente, Antonio, La prosa de Sigüenza y Góngora y la conciencia criolla mexicana, México, FCE, 1996.

Maza, Francisco de la, «Sor Juana y Don Carlos. Explicación de dos sonetos hasta ahora confusos», Cuadernos Americanos (México), 25, 1966, pp. 190-204.

Mínguez, Víctor, Los reyes distantes, Castellón, Universitat Jaume I, 1995.

Mínguez, Víctor, La fiesta barroca. Los virreinatos americanos (1560-1808), CasteIlón, Universitat Jaume I, 2012.

Morales Folguera, José, Cultura simbólica. Arte efímero en la Nueva España, Granada, Junta de Andalucía, 1991.

Rojas Garcidueñas, José, Don Carlos de Sigüenza y Góngora. Erudito barroco, México, Ediciones Xochitl, 1945.

Sigüenza y Góngora, Carlos, Obras históricas, México, Porrúa, 1960. 